\title{
STEEL AND CONCRETE ELASTO-PLASTIC MODELS AT BRIDGES WITH STEEL BEAMS EMBEDDED IN CONCRETE
}

\author{
Stănescu Răzvan Marian, Assistant Lecturer, PhD, Faculty of Railways, Roads and Bridges, \\ Technical University of Civil Engineering Bucharest, Romania, e-mail: \\ razvan.stanescu@yahoo.com
}

\section{Rezumat}

Pentru domeniul deschiderilor mici $(\mathrm{L} \leq 35.00 \mathrm{~m}$ ) la podurile feroviare noi se recomandă şi se utilizează suprastructurile cu grinzi metalice înglobate în beton, cu care se pot asigura exigenţele de rezistenţă şi mai ales de rigiditate, indiferent de viteza de circulaţie. Acestea se execută relativ uşor în comparaţie cu structurile din beton armat sau cele integral metalice, au durabilitate mare dacă sunt proiectate, executate şi întreţinute corect şi nu au sensibilitate mare la fenomenele de degradare prin oboseală în exploatare. De asemenea acestea se folosesc și pentru podurile rutiere când se dorește realizarea unei înălțimi de constructie redusă.

În toate prescripţiile de proiectare utilizate până în prezent pentru structurile cu grinzi metalice înglobate în beton, calculul este unul simplificat, realizat pe o singură grindă longitudinală izolată din tablier, dacă se îndeplinesc anumite condiţii legate de geometria structurii (oblicitate, curbură). De asemenea se adoptă simplificări și în ceea ce privește starea de deformare a tablierelor realizate în această soluţie constructivă, prin introducerea în calculul deplasărilor a unui moment de inerție efectiv, calculat ca medie a momentelor de inerție ale secțiunii transversale, considerată fisurată şi, respectiv, nefisurată.

Articolul își propune să valideze modele de comportare elasto-plastică pentru oțel și beton, pe baza unui experiment preluat din literatura tehnică de specialitate, necesare pentru analize complexe referitoare la procentul de beton ce participă la rigiditatea secțiunilor transversale în cazul podurilor cu grinzi metalice înglobate în beton.

\section{Cuvinte cheie: oțel, beton, elasto-plastic, neliniaritate geometrică.}

\section{Abstract}

For new railway bridges with short spans $(\mathrm{L} \leq 35.00 \mathrm{~m})$ superstructures with steel beams embedded in concrete are recommended or used, which can ensure the requirements of strength and stiffness in particular, regardless of velocity. They are built relatively easily compared to reinforced concrete structures or steel structures, they have high durability if designed, built and maintained correctly and don 't have high sensitivity to fatigue degradation in service. They are also used for road bridges when it is desired to achieve a reduced construction height. 
ROMANIAN JOURNAL

OF TRANSPORT INFRASTRUCTURE

Stănescu Răzvan Marian

Steel and concrete elasto-plastic models at bridges with steel beams embedded in concrete

In all the design prescriptions used so far for structures with steel beams embedded in concrete, the calculation is a simplified one, made on a single insulated longitudinal beam of the deck, if certain conditions related to the geometry of the structure are met (obliquity, curvature). Simplifications are also made regarding the state of deformation of the decks made in this constructive solution by introducing an effective moment of inertia in the displacement calculation, as an average of the inertia moments of the cross section considered to be cracked and respectively un-cracked.

The article aims to validate steel and concrete elasto-plastic models, based on an experiment from the technical literature, necessary for complex analyses of the percentage of concrete involved in the stiffness of the cross-sections, in case of bridges with steel beams embedded in concrete.

Keywords: steel, concrete, elasto-plastic, geometric nonlinearity.

\section{SUMMARY OF DATA FROM TECHNICAL LITERATURE [4]}

The experimental model consists of an IPE 200 simple supported steel girder embedded in concrete (see Figure 2). The length of the experimental model is $3.00 \mathrm{~m}$, with a $2.80 \mathrm{~m}$ span (see Figure 3 ). The rectangular crosssection thus obtained has a width of $670 \mathrm{~mm}$ and a height of $270 \mathrm{~mm}$, as shown in Figure 1.
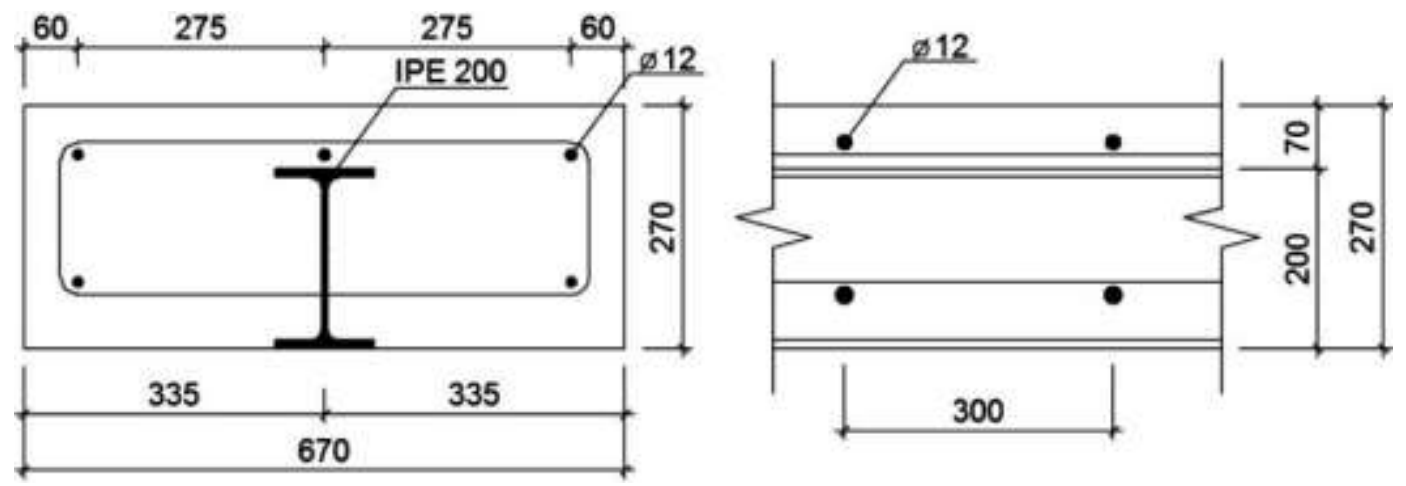

Figure 1. Beam cross-section

The concrete cover over the metal beam is $70 \mathrm{~mm}$. There are 3 longitudinal reinforcements of $\Phi 12 \mathrm{~mm}$ at the top, and 2 longitudinal reinforcements of $\Phi 12 \mathrm{~mm}$ at the bottom. The cross reinforcements of the experimental model is made with $\Phi 12 \mathrm{~mm}$ stirrups, located at an interax distance of $300 \mathrm{~mm}$.

Characteristics of the three materials used (steel in beam, concrete and steel in reinforcements) are detailed below, as follows: 
ROMANIAN JOURNAL

OF TRANSPORT INFRASTRUCTURE

Stănescu Răzvan Marian

Steel and concrete elasto-plastic models at bridges with steel beams embedded in concrete

- $\quad$ cylindrical compressive strength of concrete: $f_{c k}=25 \mathrm{~N} / \mathrm{mm}^{2}$;

- tensile strength of concrete at bending $f_{c t}=2,7 \mathrm{~N} / \mathrm{mm}^{2}$;

- $\quad$ modulus of concrete elasticity $E_{c m}=31500 \mathrm{~N} / \mathrm{mm}^{2}$;

- $\quad$ yield strength of steel $f_{y}=273 \mathrm{~N} / \mathrm{mm}^{2}$;

- $\quad$ modulus of steel elasticity $E_{a}=210000 \mathrm{~N} / \mathrm{mm}^{2}$;

- $\quad$ yield strength of reinforcement $f_{s}=500 \mathrm{~N} / \mathrm{mm}^{2}$;

- $\quad$ modulus of steel elasticity $E_{s}=200000 \mathrm{~N} / \mathrm{mm}^{2}$.

The specimen was simply placed at both edges. At one edge there was a non-elastic bearing and at the other one a horizontal shift was provided.

The specimen was charged with two vertical forces hydraulic applied (see Figure 2), arranged symmetrically with respect to the axis of symmetry of the beam, at a distance of $1 \mathrm{~m}$ from the axis of the bearing (see Figure 3). Force was applied continuously in steps of 7,5 kN, simultaneously in both presses. The model has been downloaded in two phases, namely from $60 \mathrm{kN}$ to $15 \mathrm{kN}$ and from $105 \mathrm{kN}$ to $30 \mathrm{kN}$.

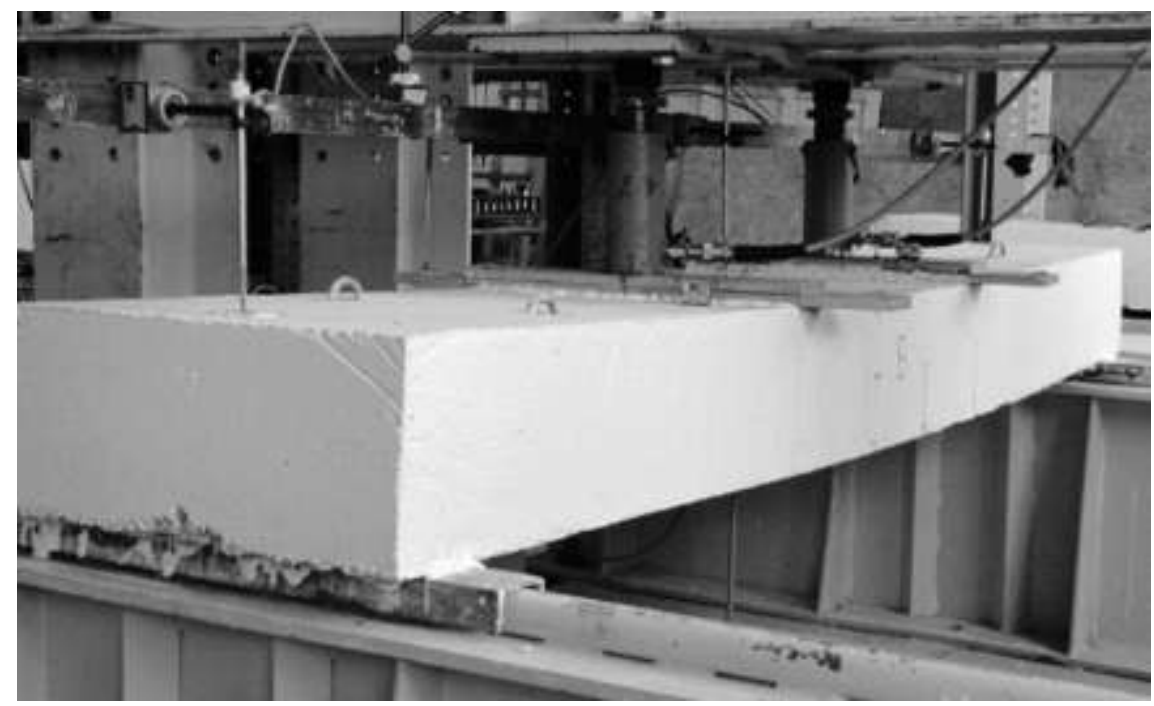

Figure 2. Experimental model 
ROMANIAN JOURNAL

OF TRANSPORT INFRASTRUCTURE

Stănescu Răzvan Marian

Steel and concrete elasto-plastic models at bridges with steel beams embedded in concrete

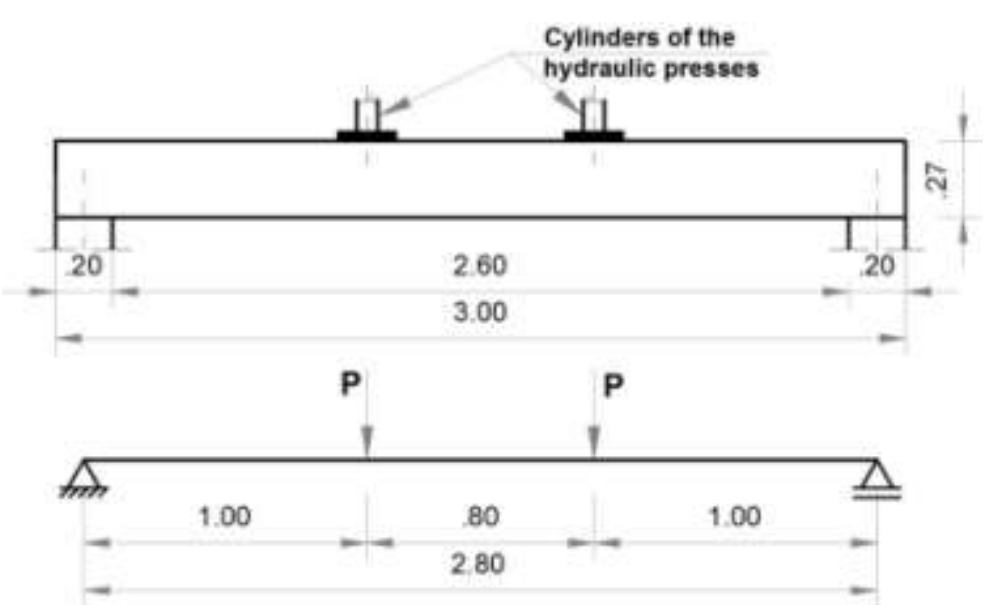

Figure 3. Elevation and static scheme of the experimental model

The beam was also analyzed with Abaqus FEA software. The analysis was carried out on a half-structure due to its symmetry, as it can be seen in Figure 4.

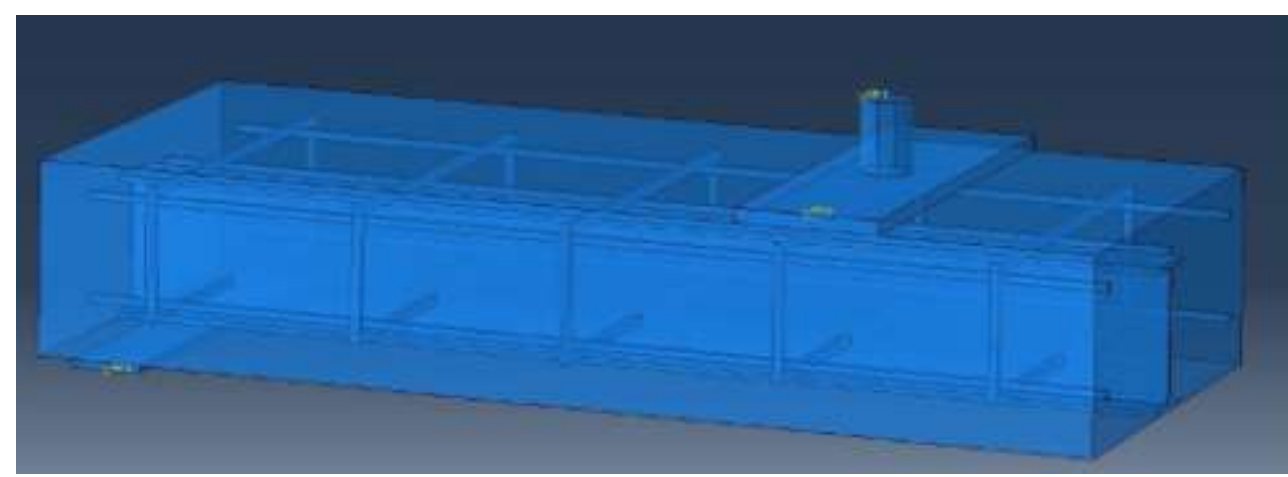

Figure 4. Space view of the calculation model

The contact between the steel and the concrete parts is modelled as a solid one.

In the analysis, the working diagrams of steel, concrete and reinforcement were taken into consideration, as they were constructed according to the experimental measurements of the materials.

The Abaqus software simulates the crack formation by the model of Concrete Damaged Plasticity - CDP. Based on experimental stress-strain curves for both uniaxial tension and compression, it is possible to define the dependence between stress - cracking strain in uniaxial tension (see Figure 5) and stress - crushing strain in uniaxial compression. 
ROMANIAN JOURNAL

OF TRANSPORT INFRASTRUCTURE

Stănescu Răzvan Marian

Steel and concrete elasto-plastic models at bridges with steel beams embedded in concrete

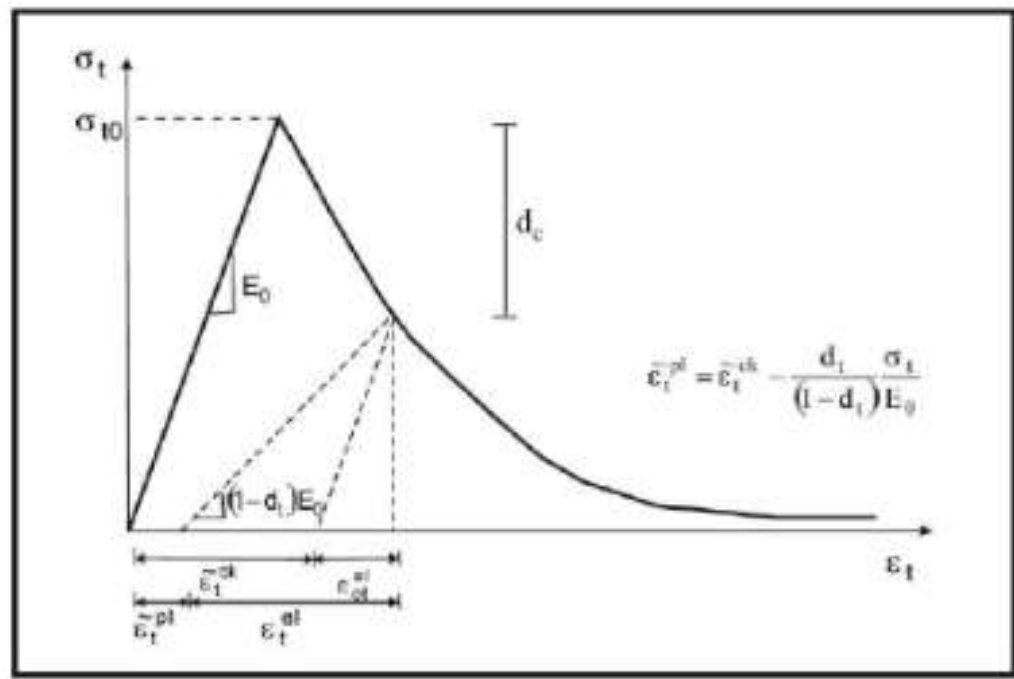

Figure 5. Dependence stress-strain in tension for CDP model

The discrete model contains 1564963 3D finite elements (see Figure 6). The Dynamics Explicit calculation model was chosen, where the time step was 0,01s. The analysis lasted 36 hours with an Intel XEON $2.4 \mathrm{GHz}, 48 \mathrm{~Gb}$ of RAM, where 6 cores of the system were utilized.

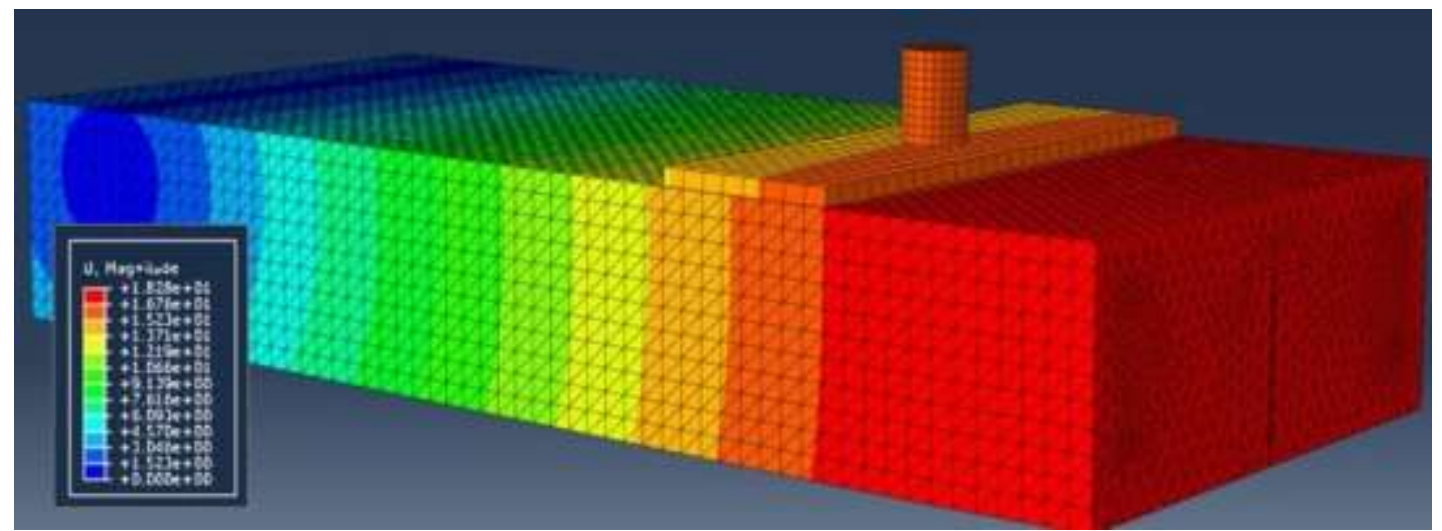

Figure 6. Finite element modeling (vertical displacements variation)

The results obtained following the experiment and with ABAQUS FEA are shown in Figure 7, as a load-maximum vertical displacement relationship. 
ROMANIAN JOURNAL

OF TRANSPORT INFRASTRUCTURE

Stănescu Răzvan Marian

Steel and concrete elasto-plastic models at bridges with steel beams embedded in concrete

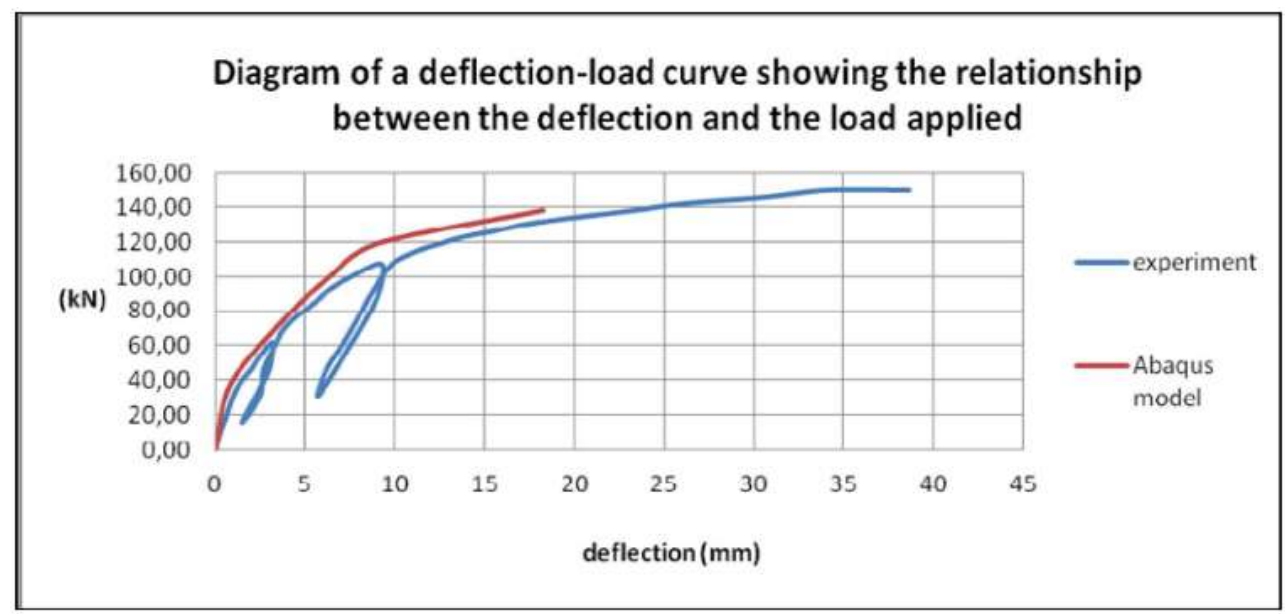

Figure 7. Load-deflection curves (experiment and Abaqus)

\section{SUMMARY OF DATA RELATED TO ELASTO-PLASTIC MODELS IMPLEMENTED IN THE LUSAS FEA SOFTWARE [5]}

For beam and reinforcements steel, an elasto-plastic model ("Stress Potential") based on the Von Mises flow criterion was used (see Figure 8).

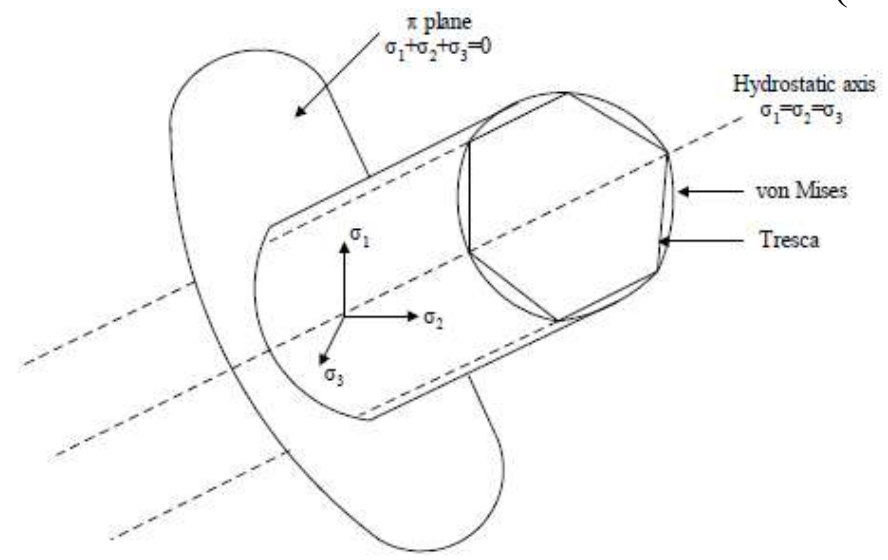

Figure 8. Von Mises and Tresca yield criteria

For concrete, an elasto-plastic model specific to the Lusas software was used (multi-cracked concrete), based on Jefferson's theory. The model is developed in a formal plastic-damage-contact framework. The model couples directional damage with plasticity and employs contact mechanics to simulate crack opening and closing and shear contact effects. The model is thermodynamically consistent, non-negative energy is produced on any loading cycle. A key aspect of the model is the derivation of a so-called „Total-local ${ }^{\text {ee }}$ condition that ensures that both the local and total constitutive relationships are satisfied. 
ROMANIAN JOURNAL

OF TRANSPORT INFRASTRUCTURE

Stănescu Răzvan Marian

Steel and concrete elasto-plastic models at bridges with steel beams embedded in concrete

The model uses so-called planes of degradation. The model assumes that at a material point there is a predefined number of possible fracture directions. The number and orientation of these cracks are chosen so that the yield criteria is not exceeded in any direction. The local coordinate system for a crack plane is illustrated in Figure 9.

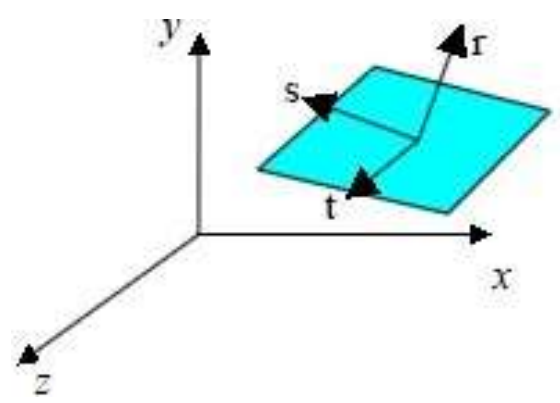

Figure 9. Plane of degradation (POD). Local and global co-ordinate systems

It is supposed that a plane of degradation (POD) is formed when the principal stress reaches the fracture stress $\left(f_{t}\right)$ and this is formed normal to the major principal axis. Thereafter, it is assumed that damage on the plane can occur with both shear and normal strains. Three states of contact are defined for a crack plane that are termed open, interlock and closed (see Figure 10).

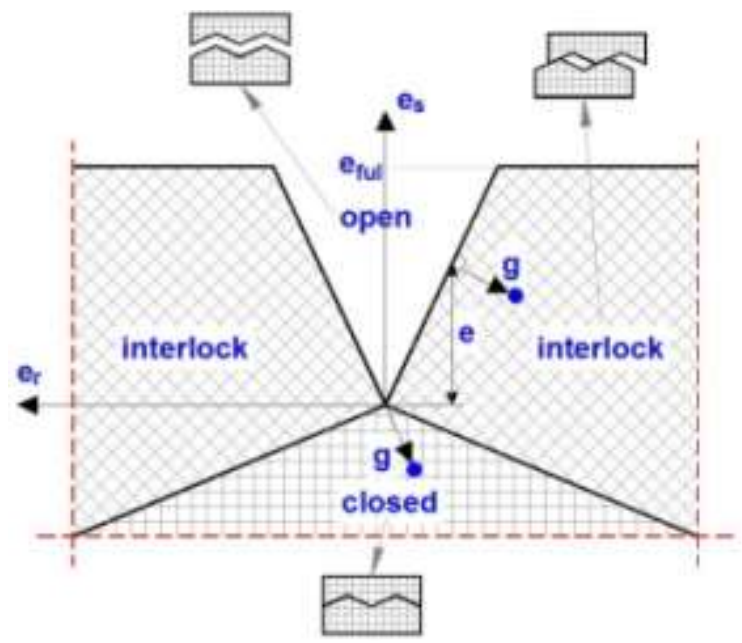

Figure 10. Local contact states

In the open state the stress in the debonded component is assumed zero. In the interlock state the debonded stress is derived from a contact law in which the stress is assumed to depend on the distance (in local strain terms) to the contact surface that is denoted by the vector $\{g\}$. In the closed state, $\{g\}$ is equal to the 
ROMANIAN JOURNAL

OF TRANSPORT INFRASTRUCTURE

Stănescu Răzvan Marian

Steel and concrete elasto-plastic models at bridges with steel beams embedded in concrete

local strain vector $\{e\}$ since the contact point coincides with the origin of the local strain space.

In the model is implemented a predictive and target damage evolution function (see Figure 11) designed to improve the numerical performance of the model, and for this purpose a completely continuous exponential softening curve, which has a smooth transition from undamaged to damaged states and from the pre-peak to the post-peak region has been introduced. The model assumes that the material can soften, and eventually lose all strength in positive loading, in any of the pre-defined cracking directions.

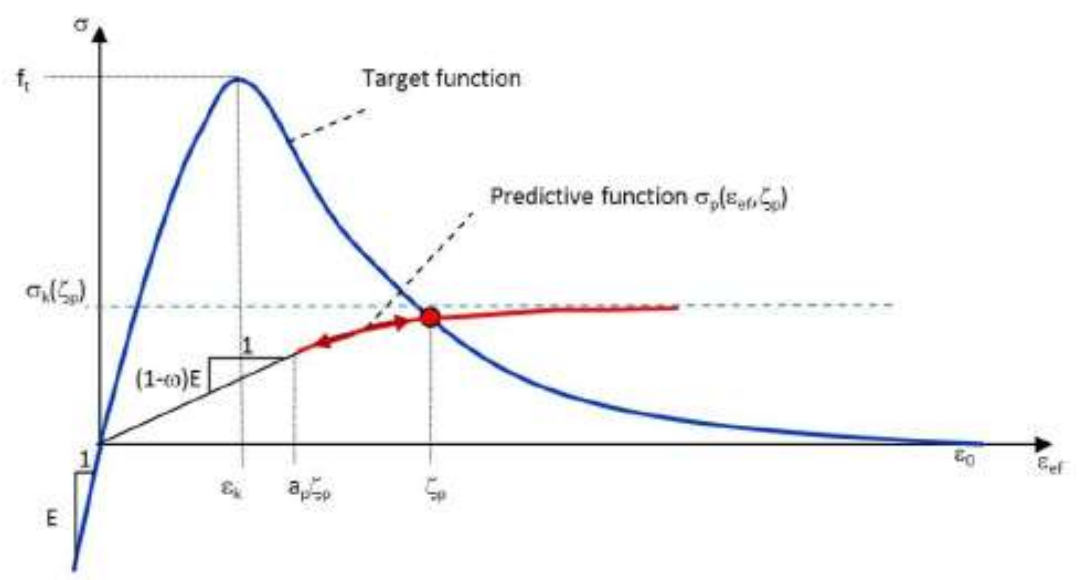

Figure 11. Predictive and target damage evolution functions

\section{PRESENTATION OF THE RESULTS OBTAINED USING THE ELASTO-PLASTIC MODELS IMPLEMENTED IN THE LUSAS FEA SOFTWARE}

The steel beam and the embedding concrete were exclusively modelled with 3D finite elements HX20, and the longitudinal reinforcement with 1D finite elements BAR3 (for convenience, the cross reinforcements were not taken into account). Thus, the obtained discrete model contains 3198 HX20 finite elements (steel beams and embedding concrete) and 155 BAR3 finite elements (reinforcements), resulting in 140000 nodes and 40000 degrees of freedom (see Figure 12). Before the nonlinear analysis the discrete model was carefully calibrated, in terms of the dimensions of the finite elements.

The materials were chosen with the nonlinear characteristics presented in paragraph 2 .

The model was loaded in steps of $7.5 \mathrm{kN}$ without any download phase. 
ROMANIAN JOURNAL

OF TRANSPORT INFRASTRUCTURE

Stănescu Răzvan Marian

Steel and concrete elasto-plastic models at bridges with steel beams embedded in concrete

The geometric nonlinear analysis formulation was chosen as "Updated Lagrangian".

The analysis was carried out on an INTEL i7-7700HQ, 3,80 GHz, 24 GB DDR4, and lasted 13 hours.

Below there are some results of the nonlinear analysis.

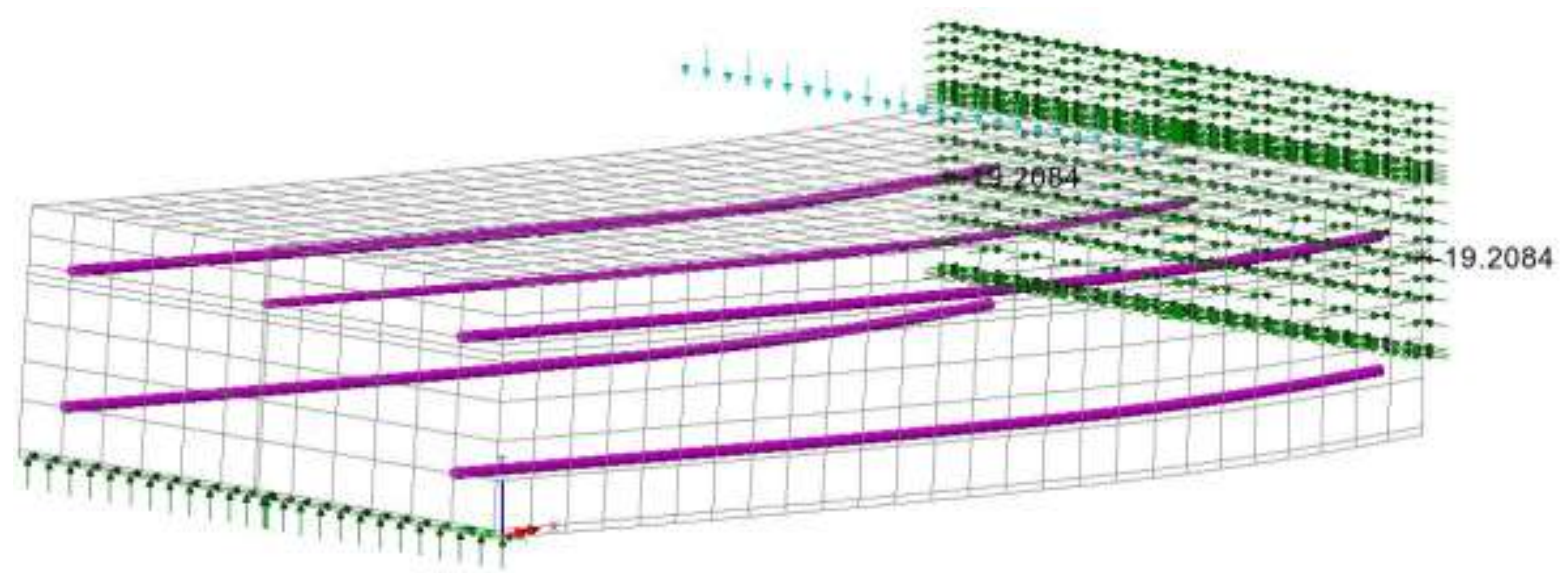

Figure 12. The deformed mesh at maximum load and the corresponding maximum vertical displacement $(\mathrm{mm})$

Figure 13 shows the state of cracking/crushing in concrete according to the "multi-cracked concrete" model implemented in Lusas FEA software, with the observation that the planes of degradation are represented on a deformed scale to be able to view the entire model.
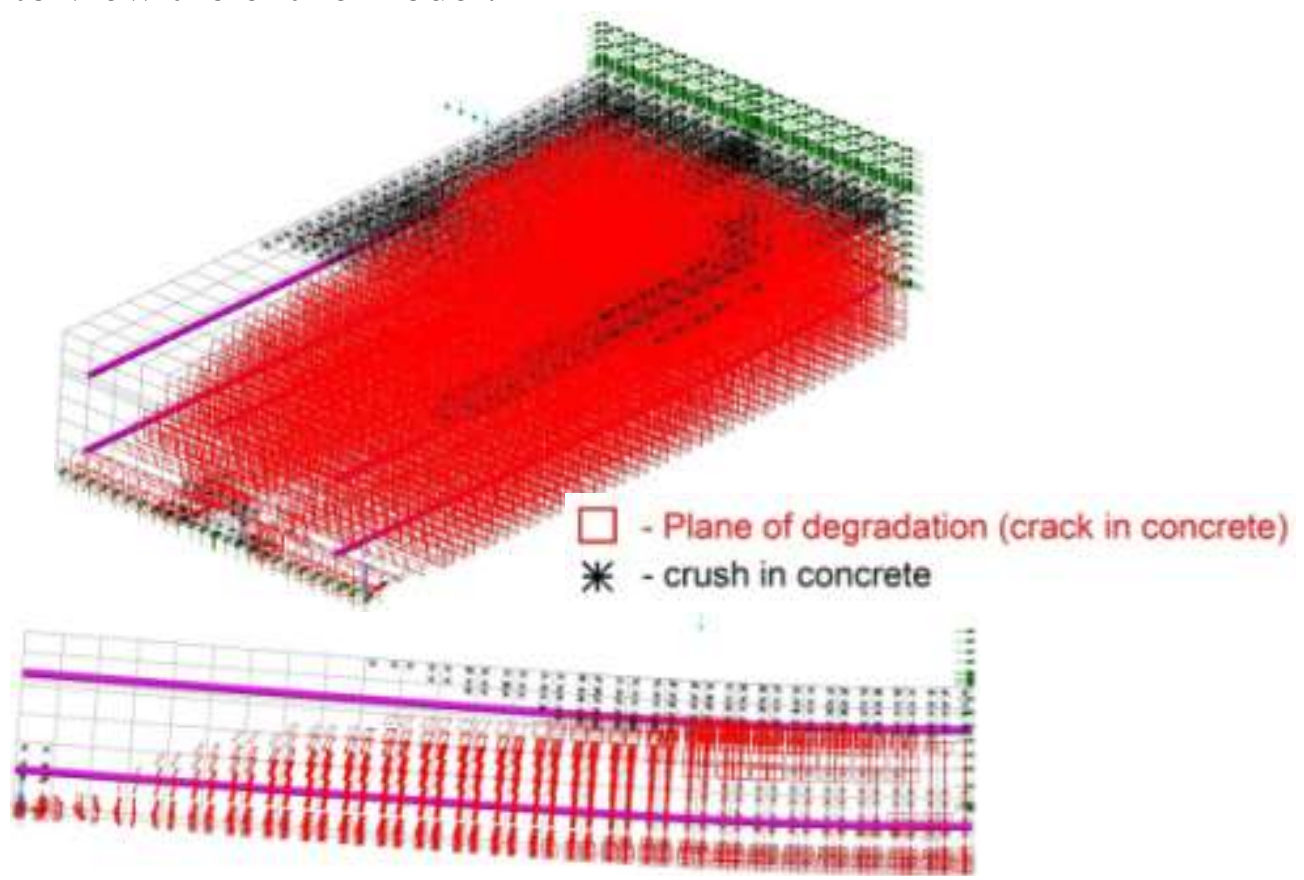

Figure 13. Crack/crush in concrete (3D/2D) 
ROMANIAN JOURNAL

OF TRANSPORT INFRASTRUCTURE

Stănescu Răzvan Marian

Steel and concrete elasto-plastic models at bridges with steel beams embedded in concrete

From the results of the analysis, the load - maximum vertical displacement curve represented in Figure 14 was obtained, in order to be able to compare it with the curves taken from the technical literature.

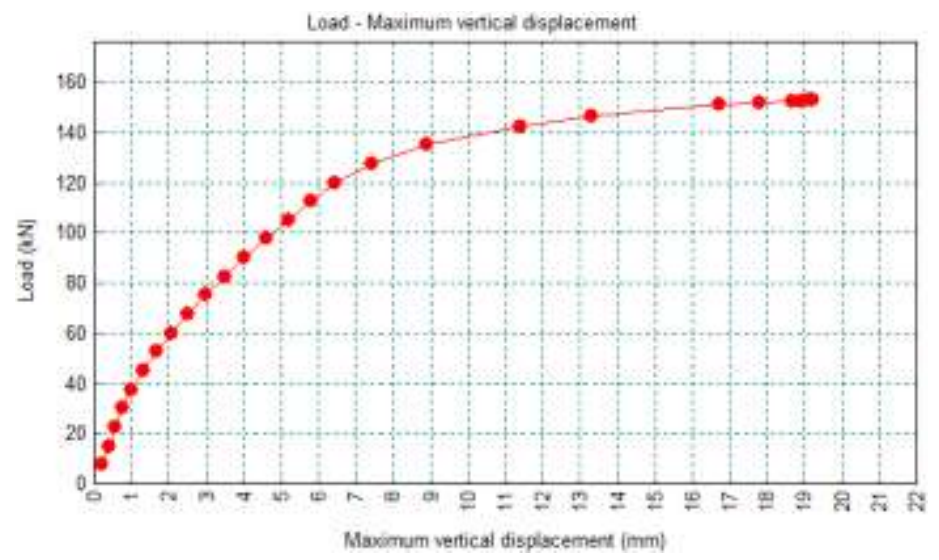

Figure 14. The load - maximum vertical displacement curve obtained with LUSAS FEA software

From the analysis, the $\sigma_{x}$ variation on height of the middle span section for the maximum load was extracted, in the composite section zone and in the concrete section zone (see Figure 15). The non-linear variation of $\sigma_{x}$ is represented in figure 16, with the observation that different representation scales were used for the two analyzed sections. The values of $\sigma_{x}$ are in $N / \mathrm{mm}^{2}$.

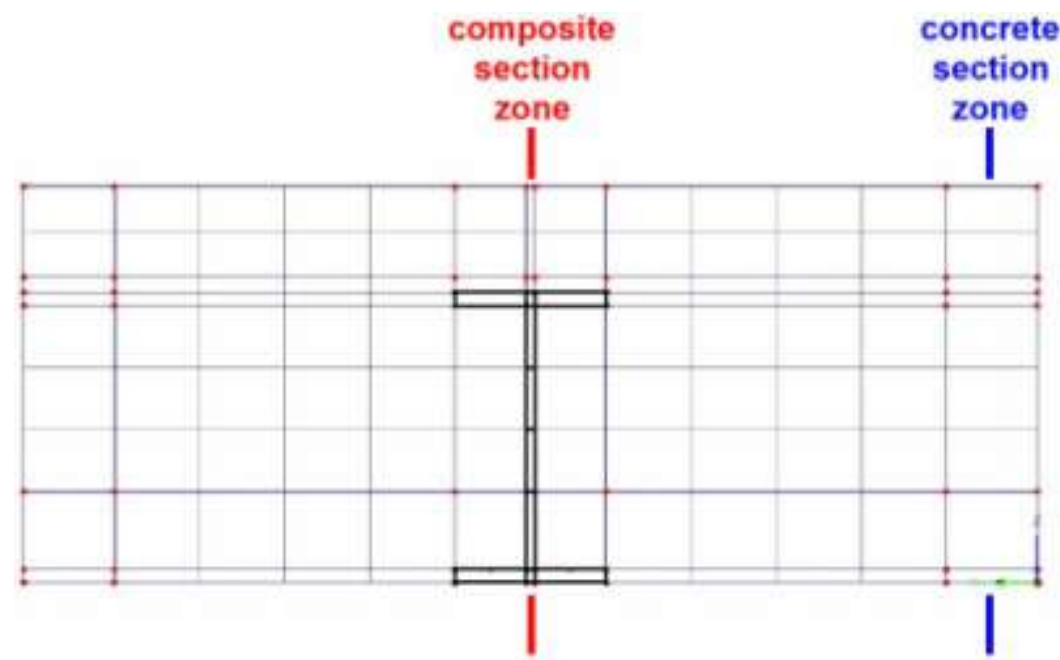

Figure 15. Composite section zone and concrete section zone 
ROMANIAN JOURNAL

OF TRANSPORT INFRASTRUCTURE

Stănescu Răzvan Marian

Steel and concrete elasto-plastic models at bridges with steel beams embedded in concrete

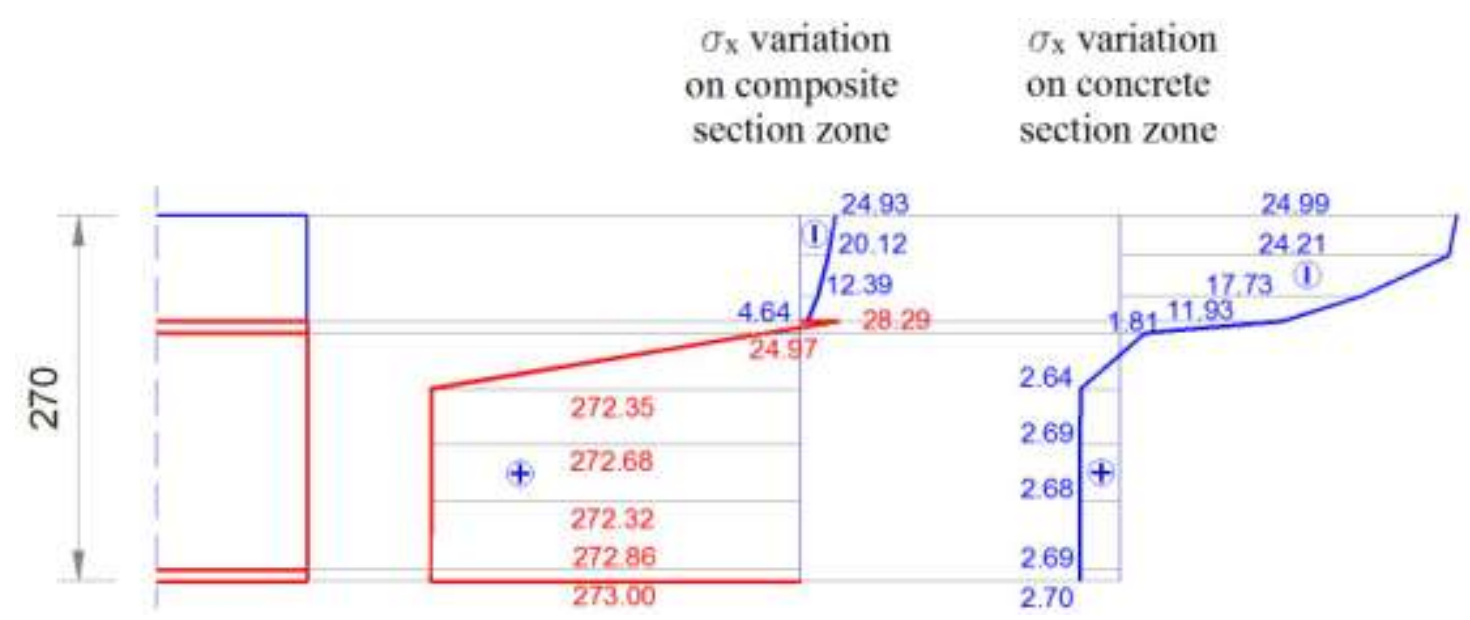

Figure 16. $\sigma_{x}$ variation on the section height in the two materials (steel and concrete)

As Figure 16 shows, the $\sigma_{x}$ variation diagram is close to the idealized plastic diagram.

\section{CONCLUSIONS}

By overlapping the curve obtained from the analysis performed with those taken from the technical literature (see Figure 17) we can see that the results in maximum vertical displacements have close values, with the difference that the discrete model analyzed develops a slightly higher rigidity than the experimental model and that used in the Abaqus FEA software. The difference in rigidity can be attributed to the fact that the discrete model refinement degree is small as compared to that used in the example taken from the technical literature, as well as to the fact that the selected example uses the experimentally determined characteristics of the materials (steel in beam, concrete and steel in reinforcements). Also, in the discrete model used, load conditions are simplified by applying a uniformly distributed load on a line, compared to the example taken from the technical literature where the loading mechanism from the presses to the beam is thoroughly discretized. 
ROMANIAN JOURNAL

OF TRANSPORT INFRASTRUCTURE

Stănescu Răzvan Marian

Steel and concrete elasto-plastic models at bridges with steel beams embedded in concrete

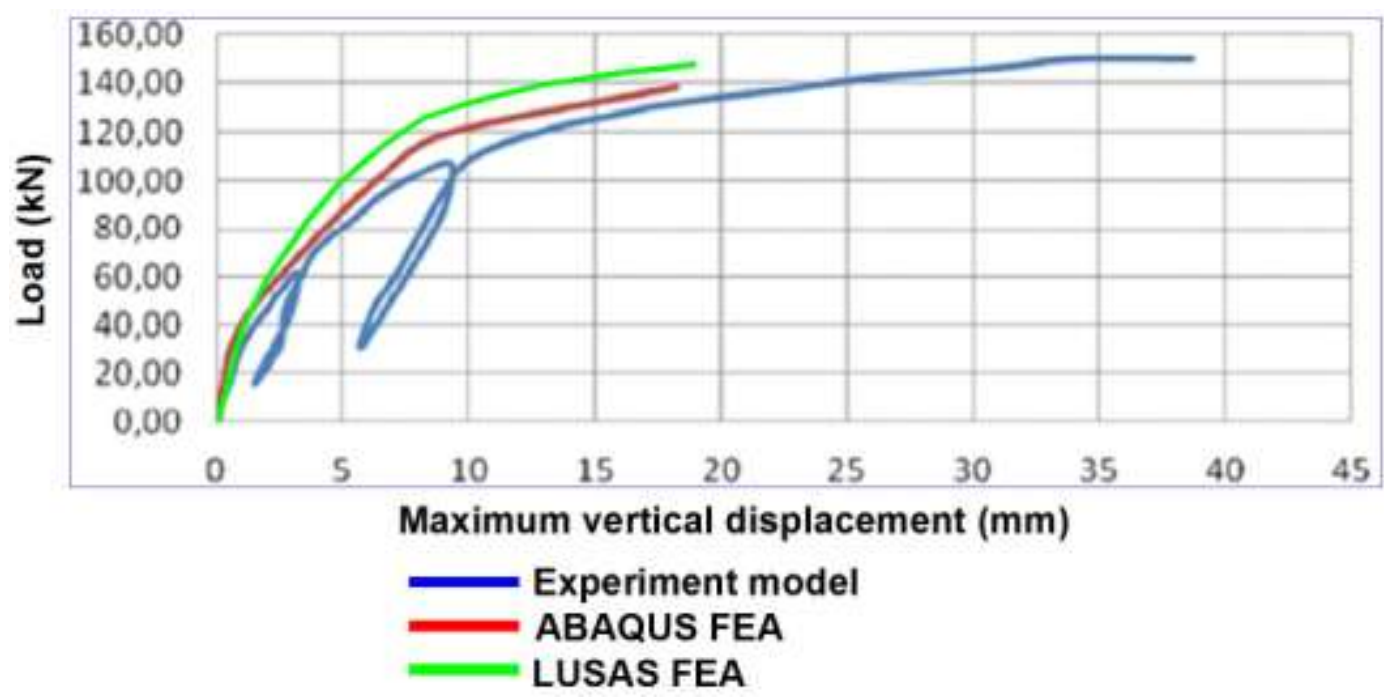

Figure 17. Comparative study of load - maximum vertical displacement curves

The two large consolidation regions (in the meaning of change of stiffness) may be oberved in the obtained curve, also present in the curve obtained with Abaqus analysis.

As well, it may be also noted that the maximum load reached is the same as that obtained in the experiment.

From the comparative analysis of the results, it can be concluded that the selected elasto-plastic models can be used further, in order to perform complex analyses regarding the percentage of concrete that contributes to the stiffness of the cross-sections, in case of the concrete beams embedded in concrete.

\section{REFERENCES}

[1]. ***, "UIC Code 773-4 R”, International Union of Railways, F-75015 Paris, 1997

[2]. ***, EN 1992-1-1:2004, "Eurocode 2: Design of concrete structures - Part 1: General rules and rules for buildings", 2004

[3]. ***, EN 1994-2:2005, "Eurocode 4: Design of composite steel and concrete structures - Part 2: General rules and rules for bridges", 2005

[4]. Kvočák V., Tomko M., Kožlejová V., "Modelling of Encased Steel Beams in Abaqus Program" - INES 2013 - IEEE 17th International Conference on Intelligent Engineering Systems - June 19-21, 2013, Costa Rica

[5]. ***, “Element Reference Manual”, LUSAS Finit Element Analysis, Version 15.0

[6]. Jefferson A.D., "Craft, a plastic-damage-contact model for concrete. Part II-Model 
ROMANIAN JOURNAL

\section{OF TRANSPORT INFRASTRUCTURE}

Stănescu Răzvan Marian

Steel and concrete elasto-plastic models at bridges with steel beams embedded in concrete

implementation with implicit return-mapping algorithm and consistent tangent matrix", International Journal of Solids and Structures, Vol. 40, No. 22, 2003

[7]. Bazant Z. P., Oh B. H., "Crack band theory for fracture of concrete", Materials and Structures (RILEM, Paris), Vol. 16, 1983

[8]. Carol I., Bazant Z. P., "New developments in micro-plane and multicrack models for concrete”, In Proceedings of FRAMCOS2, ed. Wittmann, F. H. Aedificatio, Germany, 1995

[9]. De Borst R., Nauta P., "Non-orthogonal cracks in a smeared finite element model", Engineering and Computations, Vol. 2, 1985

[10]. Stănescu R.M., "Study of influence of the track curvature and supports obliquity at railway bridge structures with steel beams embedded in concrete", $\mathrm{PhD}$. Thesis, T.U.C.E. Bucharest, Romania, 2016 